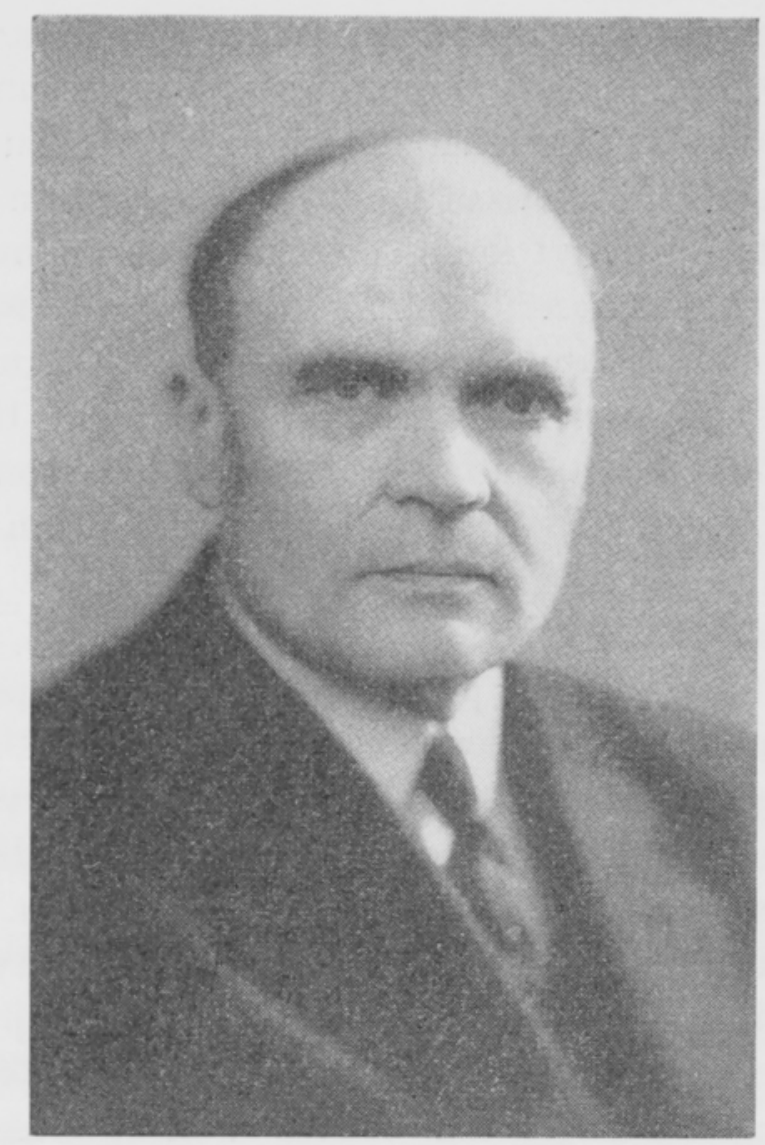

\title{
LAURI ALEKSANTERI KESO
}

\author{
* 12. 9. $1888-\dagger 1.2 .1954$.
}

Helmikuun 1 päivänä 1954 kuoli Helsingissä Salaojitusyhdistyksen toimitusjohtaja professori LaUri Aleksanteri Keso. Hän oli syntynyt maanviljelijän poikana Aitolahdella syyskuun 12 p:nä 1888. Vanhan hämäläisen talonpoikaissuvun jäsenenä hän tunsi jo nuoruudestaan lähtien kiintymystä maanviljelykseen, johon hänellä oli tilaisuus jo koulunkäyntinsä aikana kotitalossaan osallistua.

Keso tuli ylioppilaaksi Tampereen realilyseosta 1908, valmistui maanviljelysinsinööriksi 1913, agronomiksi 1914, pääaineinaan maanviljelystalous ja maanviljelysoppi, sekä tekniikan tohtoriksi 1935 pääaineinaan kulttuuritekniikka, maanviljelyskemia ja -fysiikka. Hänen väitöskirjansa käsitteli aihetta »Kulttuuriteknillisiä maaperätutkimuksia erikoisesti ojaetäisyyttä silmällä pitäen». Professorin arvonimi hänelle myönnettiin 1943.

Toimittuaan Uudenmaan ja Hämeen piirin apul. maanviljelysinsinöörinä sekä asutushallituksen insinöörinä vuosina 1916-1920, Keso tuli vuonna 1921 Suomen Salaojitusyhdistyksen toimitusjohtajaksi. Hän oli hoitanut tätä tehtävää siihen määrättynä päätoimensa ohessa jo yhdistyksen perustamisesta lähtien vuosina 1919-1920. Salaojitusyhdistyksen palveluksessa Keso oli sitten yhtäjaksoisesti kuolemaansa saakka, lukuunottamatta vuosia 1946-1948, jolloin hän toimi maataloushallituksen yli-insinöörinä. Toimensa ohella hän hoiti myöskin Helsingin 
Yliopiston maanviljelystekniikan opettajan tointa vuodesta 1936 lähtien. Keson asiantuntemusta käytettiin lukuisissa komiteoissa ja toimikunnissa joihin hän kuului joko puheenjohtajana tai jäsenenä, näistä mainittakoon Helsingin maalentokenttäkomitea, kulttuuriteknillisen tutkimus- ja koetoiminnan asiantuntijakunta, maanparannushankkeita käsitellyt komitea, sekä Teuravuoman toimikunta. Keso oli myös Pietarsaaren konepajan johtokunnan jäsenenä 1933-1935, Maatalouskoneiden tutkimuslaitoksen johtokunnan jäsenenä ja Keskinäisen Vakuutusyhtiö Kalevan hallintoneuvoston jäsenenä vuodesta 1947 lähtien. Hän oli Pohjoismaiden Maataloustutkijain Yhdistyksen kulttuuriteknillisen jaoston asiamies Suomessa. Keso teki lukuisia opintomatkoja miltei kaikkiin Euroopan maihin sekä Yhdysvaltoihin ja Kanadaan.

Keson julkaisutoiminta käsitti salaojituksen merkitystä, sen tekniikkaa ja siihen liittyviä aiheita, mutta myös peltoviljelyksen voimaperäistämistä ja maatalouden perusparannuskysymyksiä yleensä mm. kastelua. Hänen pääteoksensa "Salaojitustyöt» ilmestyi kolmantena, uusittuna ja täydennettynä painoksena v. 1951. Samana vuonna kirjoitti hän myös "Salaojitusmenetelmistä» selvittäen siinä meikäläisen salaojituksen suunnittelu- ja suoritusperusteita.

Varsinaisen elämäntyönsä Keso suoritti Salaojitusyhdistyksen johdossa. Salaojitusyhdistyksen perustamisen aikoihin saakka oli salaojitustoiminta vähäistä maassamme ja yleinen käsitys oli ollut että tämä ojitustapa oli oloihimme soveltumaton. Uranuurtajan vaikeassa työssä oli Keson ensimmäisenä tehtävänä noiden ennakkoluulojen voittaminen. Keso syventyi koko hämäläisen luonteensa sitkeydellä ja tiedemiehen lahjomattomuudella salaojituskysymyksiin, huomioiden niissä meikäläiset erikoiset olosuhteet. Hän asetti salaojituksen suunnittelussa ja itse työn suorituksessa laatuvaatimukset varsin korkealle, jotta työ kerran suoritettuna koituisi useamman sukupolven hyödyksi.

Professori Keson elämäntyö on muodostanut perustan Salaojitusyhdistyksen toiminnalle ja vastaiselle kehitykselle, mutta on sillä myös merkittävä osuutensa koko maataloutemme edistämistä tarkoittavissa pyrkimyksissä. Salaojitusasiaan liittyvien kysymysten tutkijana sekä käytännöllisen salaojitustyön ohjaajana ja valvojana on hänelle annettu tunnustusta maamme rajojen ulkopuolellakin.

Keso tunnettiin henkilönä, joka koko sydämestään oli omistautunut sen asian edistämiseen, jonka hän oli katsonut kaiken työnsä ja harrastuksensa arvoiseksi. Hänen työtoverinsa kunnioittivat häntä oikeudenmukaisena ja innoittavana esimiehenä sekä elämänmyönteisenä ja lämminsydämisenä ihmisenä.

Viljo Hintikka. 


\section{LAURI ALEKSANTERI KESO}

*12. 9. $1888-\dagger$ 1.2. 1954.

Am 1. Februar 1954 entschlief in Helsinki der Direktor des Dränungsvereins, Professor Lauri Aleksanteri Keso. Er wurde am 12. September 1888 als Sohn eines Landwirtes in Aitolahti geboren. Als Angehöriger einer alten tawastländischen Bauernfamilie fühlte er schon in seiner Jugend Neigung zum Ackerbau, an dem er schon während seiner Schulzeit auf dem Familiengut teilzunehmen Gelegenheit hatte.

Keso bestand 1908 die Reifeprüfung am Reallyzeum zu Tampere, wurde 1913 Kulturingenieur, 1914 Agronom, wobei seine Hauptfächer Landwirtschaftsökonomie und Landwirtschaftskunde waren, darauf 1935 Doktor der Technik und zwar mit den Hauptfächern Kulturtechnik, Ackerbauchemie und -physik. Seine Doktordissertation behandelte das Thema "Kulttuuriteknillisiä maaperätutkimuksia erikoisesti ojaetäisyyttä silmälläpitäen» (Kulturtechnische Bodenuntersuchungen mit besonderer Berücksichtigung der Strangentfernung). Im Jahre 1943 wurde ihm der Professorstitel zuerkannt.

Nachdem Keso 1916-1920 als assist. Kulturingenieur des Bezirks Uusimaa und Häme und als Ingenieur des Kolonisationsamtes tätig gewesen war, wurde er im Jahre 1921 Direktor des Dränungsvereins "Suomen Salaojitusyhdistys". Er hatte diese Stellung bei seiner Ernennung neben seinem Hauptamt schon seit der Gründung des Vereins in den Jahren 1919-1920 innegehabt. Im Dienste des Dränungsvereins blieb Keso dann fortgesetzt bis zu seinem Tode, ausschliesslich der Jahre 1946-1948, als er als Oberingenieur der Landwirtschaftsverwaltung arbeitete. Neben seinem Amte gab er auch von 1936 an an der Universität Helsinki Unterricht in Kulturtechnik. Kesos Sachkenntnis benutzte man in mehreren Ausschüssen und Komitees, zu denen er entweder als Vorsitzender oder als Mitglied gehörte und von denen folgende erwähnt seien: Helsingin maalentokenttäkomitea (Komitee für das Landflugfeld Helsinki), kulttuuriteknillisen tutkimus- ja koetoiminnan asiantuntijakunta (Expertenausschuss für kulturtechnische Forschungsund Versuchstätigkeit), maanparannushankkeita käsitellyt komitea (Komitee für Meliorationsprojekte) und Teuravuoma-Kommission. Keso war auch 1933-1935 Mitglied im Vorstand der Maschinenwerkstatt "Pietarsaaren Konepaja", im Vorstand der Maatalouskoneiden tutkimuslaitos (Anstalt für Prüfung von Ackerbau- 
maschinen) wie auch seit 1947 im Verwaltungsrat der Gegenseitigen Versicherungsgesellschaft Kaleva. Er war Vertreter der Kulturtechnischen Abteilung der Nordischen landwirtschaftlichen Forschung in Finnland. Keso unternahm mehrere Studienreisen nach fast allen europäischen Ländern wie auch nach den USA und Kanada.

Kesos Publikationstätigkeit betraf die Bedeutung der Dränung, ihre Technik und mit ihr zusammenhängende Fragen, aber auch die Anbauintensität und Meliorationsfragen überhaupt, u.a. die Bewässerung. Sein Hauptwerk "Salaojitustyöt» (Dränungsarbeiten) erschien als dritte, erneuerte und ergänzte Auflage im Jahre 1951. In demselben Jahre schrieb er auch "Salaojitusmenetelmistä» (Über Dränungsmethoden), worin er die Planungs- und Ausführungsgründe der Dränung in Finnland darstellte.

Seine eigentliche Lebensarbeit leistete Keso in der Leitung des Dränungsvereins. Bis zur Gründung des Dränungsvereins war in Finnland die Dränungstätigkeit unbedeutend gewesen und die allgemeine Meinung dahin gegangen, dass diese Art der Entwässerung auf unsere Verhältnisse nicht anwendbar wäre. In der schweren Arbeit eines Bahnbrechers machte Keso es sich zur ersten Aufgabe, diesen Vorurteilen entgegenzutreten. Er vertiefte sich mit der ganzen Zähigkeit seiner tawastländischen Natur und der Unbestechlichkeit eines Wissenschaftlers in Dränungsfragen, wobei er die besonderen Verhältnisse Finnlands in Betracht zog. In dem Entwurf des Dränungsplanes und hinsichtlich der Ausführung der Arbeit selbst stellte er Qualität sehr hohe Forderungen, damit die Arbeit, einmal ausgeführt, mehreren Generationen zum Nutzen gereichen würde.

Professor Kesos Lebenswerk ist für die Tätigkeit und die zukünftige Entwicklung des Dränungsvereins grundlegend gewesen, aber es hat auch einen merklichen Anteil an dem Bestreben gehabt unsere ganze Landwirtschaft zu fördern. Als Erforscher von Fragen, die mit Dränung im Zusammenhang stehen und als Leiter und Überwacher praktischer Dränungsarbeiten hat er auch ausserhalb der Grenzen Finnlands Anerkennung gefunden.

Keso war bekannt als begeisterter Förderer der Angelegenheiten, die er als wert erachtet hatte, ihr seine ganze Arbeit und sein volles Interesse zu widmen. Seine Mitarbeiter achteten ihn als gerechten und begeisternden Vorgesetzten und als lebensbejahenden und warmherzigen Menschen.

Viljo Hintikka. 